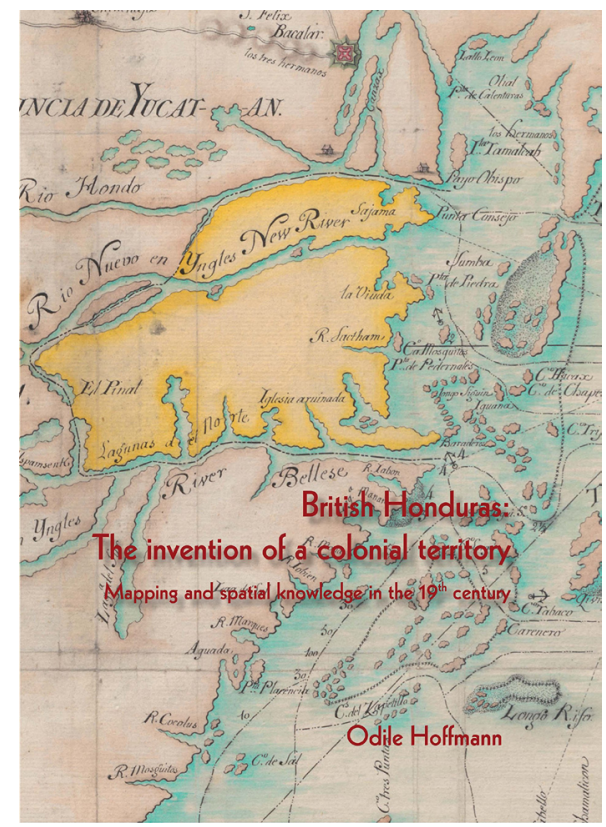

\title{
Hoffmann, Odile
}

British Honduras: The

invention of a colonial

territory. Mapping and spatial knowledge in the $19^{\text {th }}$ century

Año: 2014

Editorial: IRD-Cubola

ISBN: 978-976-8161-40-6

Páginas: 79

La historia de Belice ha sido un tema olvidado por los académicos latinoamericanos y del Caribe, que poco se han ocupado de relatarla. Por ello, los textos sobre Belice son siempre bienvenidos.

En el contexto de los países latinoamericanos y caribeños, la historia beliceña tiene un carácter particular, no sólo en su devenir interno sino también en función de los intereses externos que a lo largo del tiempo se hicieron presentes en este pequeño país, que lleva poco más de tres décadas de vida independiente y que tiene la doble identidad de centroamericano y caribeño.

Desde sus orígenes, vinculados a la actividad de los piratas en los siglos XVI y XVII, la historia de Belice estuvo signada por las disputas internacionales en torno a la soberanía sobre su territorio. En un primer momento, fueron España y Gran Bretańa quienes contendieron por hacer valer sus derechos soberanos; la primera, refrendándolos en los tratados internacionales, y la segunda, apoyada en las actividades de los cortadores británicos de palo de tinte que se habían asentado en la zona.

(cc) BY-NC-ND Páginas 178-185. 
Ya en el siglo XIX, una vez consumada la independencia de las colonias españolas, los dos nuevos actores de la disputa fueron México y Guatemala, quienes desde 1821 reclamaron la soberanía de Belice por derecho hereditario y declararon caducos los pactos anteriores. Ése fue un siglo de negociaciones que culminaron con los tratados de límites firmados por Gran Bretańa: en 1859, con Guatemala, y en 1893, con México. El primero, se convirtió en el antecedente remoto de una disputa que aún no tiene solución, mientras que el segundo tuvo una doble finalidad: establecer los límites con el país vecino, al tiempo que ponía las condiciones para lograr pacificar el sur de México, convulsionado por la Guerra de Castas.

De acuerdo con Assad Shoman, ${ }^{1}$ es en la segunda mitad del siglo XIX cuando Belice entró en un etapa de expansión territorial y formación de la nación caracterizada por un crecimiento poblacional diverso, el desarrollo de la agricultura comercial, el impulso de la industria azucarera, la progresiva influencia de Estados Unidos, las tensiones entre los mayas y los mestizos, y la consolidación de algunas instituciones, todo ello aún bajo el signo del dominio cultural criollo y el control de Gran Bretaña.

La lucha por la independencia constituyó el elemento central de la historia de Belice en el siglo XX, y tuvo su origen en el surgimiento de los sindicatos y organizaciones de trabajadores que pugnaron por el derecho al autogobierno con la idea de encaminarse a la emancipación. Alcanzado primero el autogobierno, en 1964, y después la independencia, en 1981, Belice debió abrirse paso en un complejo escenario internacional caracterizado por los años de la crisis centroamericana y el fin de la guerra fría.

Uno de los factores que hubo de enfrentar la nueva nación fue el reclamo territorial guatemalteco sobre el territorio beliceño, que contribuyó a retrasar el proceso de independencia y frenó la integración de Belice a Centroamérica. De ahí que se establecieran muchos más vínculos con los países del Caribe, que siempre mostraron su simpatía por la causa beliceña y que, junto con México, apoyaron su derecho a

\footnotetext{
${ }^{1}$ Historia de Belice: El surgimiento de una nación centroamericana (del siglo XVII al XXI), México, CIALC (UNAM), 2010, 292 p.
} 
la independencia y a la autodeterminación en los distintos foros internacionales en donde el asunto se dirimió.

Quiero empezar señalando que la autora de este libro es geógrafa del Institut de Recherche pour le Développement (IRD), en Francia, y labora en el laboratorio URMIS de la Universidad Paris Diderot. Se ha dedicado a desarrollar estudios de las dinámicas políticas y territoriales en México, Colombia y Belice, articulándolos con el análisis acerca de las problemáticas étnicas y raciales. Actualmente, es directora del laboratorio mixto internacional MESO (Movilidad, Gobernanza y Recursos en la Cuenca Mesoamericana) y, con David Garibay, es coredactora de la revista Cahiers des Amériques latines.

El planteamiento central que nos presenta Odile Hoffmann en su libro es muy claro: los mapas dan cuenta de las espacialidades que conjuntamente constituyen un saber geográfico sobre la nación, lo cual, en un contexto colonial, significa dar cuenta sobre porciones de tierra que una nación reivindica como suyas. La autora destaca que no son simples instrumentos, sino prácticas textuales que tejen las relaciones sociales y de poder, revelando las lógicas y los intereses de los actores que participan en su elaboración, creación y utilización.

En su opinión, los mapas dan testimonio, a la vez que acompañan, los fenómenos de dominación y de resistencia, y en ocasiones pueden también orientarlos. De aquí que su trabajo tenga como fin principal reflexionar acerca de la dimension imperial o colonial de los territorios, de la función eminentemente política de las representaciones del espacio y del potencial opresivo o emancipador de estas representaciones. Su objetivo último es dar cuenta de la invención de un territorio colonial, fundamentalmente a través de la interpretación de su cartografía, producida en el siglo XIX.

Una de las prácticas más inmediatas entre los colonizadores europeos en América fue la re-denominación de los lugares con el fin de familiarizar el territorio para algunos o volverlo extrańo a otros. Así, explica la autora, en una lógica de conquista y colonización, el mapa ocupa un lugar preponderante, en tanto medio y producto de la autoridad. Recalca cómo el mapa es un objeto político que modela y a la vez refleja la realidad misma que supone representar de manera 
transparente y constituye una visión específica del mundo, es decir, contiene en el fondo la elaboración de una política geográfica.

En el libro se desarrollan varios conceptos para entender el papel político de la cartografía: ningún territorio existe por sí mismo, sólo el trabajo de construcción social, política y simbólica le proporciona sustancia y realidad. En ese marco, la cartografía se convierte en una herramienta que contribuye a forjar los imaginarios colectivos y, a través de la circulación de símbolos impresos, dibuja a las comunidades que se reconocen en la idea de nación. De aquí que los mapas proporcionen un soporte material a esas composiciones sociales, culturales y políticas. Sobre esta base, Odile Hoffmann propone un análisis puntual de la cartografía elaborada por los poderes imperiales y coloniales en lo que era Honduras Británica, hoy Belice.

Asimismo, concibe los mapas no como productos aislados, sino elaboraciones que proporcionan información tanto en su forma como en su contenido. No obstante, la autora no pretende ofrecer una visión exhaustiva del uso y manipulación de la cartografía colonial, sino más bien analizar algunos procesos políticos y culturales basados en estas prácticas de manejo del espacio y sus representaciones, a partir del análisis del caso de Honduras Británica a lo largo del siglo XIX.

Por ello, el estudio es organizado por Hoffmann a partir de cuatro grandes temas: las disputas territoriales entre las potencias coloniales, el establecimiento de la propiedad, el control administrativo y la expresión de los intereses científicos o comerciales.

Los mapas y fondos documentales fueron consultados en los Archivos de Belice en Belmopan, en Londres — principalmente los de Colonial Office- y en París, en la Biblioteca Nacional de Francia; también se revisaron obras de gran importancia realizadas por historiadores, geógrafos y antropólogos, quienes rescataron y comentaron la mayoría de los mapas históricos existentes sobre esta región.

Algunos de ellos pueden encontrarse en la compilación realizada en 1992 por Michel Antochiw y Alain Breton, ${ }^{2}$ la cual contenía 76 mapas realizados entre 1511 y 1880 . Sin embargo, además de que esta publicación — que por cierto era sólo en blanco y negro- ya no está

${ }^{2}$ Catálogo cartográfico de Belice (1511-1880), BPR Publishers, Belize, 1992, 206 p. 
disponible para el público beliceño, no incluía una labor como la que hace Odile Hoffmann en este libro, gracias a la cual pone en contexto y ofrece una interpretación para hacer accesible al lector la información contenida en los mapas.

La autora parte de señalar cómo la política geográfica de Honduras Británica empezó para los europeos con la instalación precaria de sujetos británicos en la costa sur de la península de Yucatán en el siglo XVII. A través del análisis de diversas situaciones significativas de redefiniciones territoriales, explica cómo las autoridades de Honduras Británica, primero como asentamiento y luego como colonia, asentaron su legitimidad movilizando, a través de su dominio de los mapas, el saber imperial, que más tarde se transformaría en un saber militar.

Durante muchas décadas, sostiene Hoffmann, los cortadores de madera no reivindicaron un vínculo especial con alguno de los dos imperios que disputaban la soberanía en el área —el español y el británico-, y se autonombraban "hombres de la Bahía" (baymen), sin referencia alguna de nacionalidad. Sin embargo, a finales del siglo XVIII, los imperios decidieron acordar sus derechos respectivos sobre las tierras e islas de la región y terminar así sus largas batallas y guerras marítimas.

Desde su perspectiva, fue entonces cuando comenzó el proceso de definir quién tenía legitimidad para estar en un lugar u otro, es decir, definir las fronteras entre los espacios, así como los derechos y obligaciones que incumbían a los miembros de cada comunidad. Ahí es donde intervinieron las representaciones cartográficas que se analizan en una parte de este texto, con base en los mapas elaborados por el poder colonial.

Estos mapas, concluye Odile Hoffmann, son instrumentos con múltiples funciones. Sirven para describir el espacio, pero también para explicar su historia y la de sus habitantes. De aquí que, en el siglo XVIII, estén producidos por las autoridades coloniales españolas, francesas y británicas que intervenían en las negociaciones para regular una instalación — sin colonización — de los sujetos británicos, reduciéndolos a ser solamente cortadores de madera. Sin embargo, apunta la autora, el devenir del territorio demostró que no se restringieron a este papel sino que, al contrario, sembraron las bases de una sociedad colonial compleja. 
Asimismo, en el libro se analiza otro momento de movilización alrededor de las fronteras y de la definición de derechos territoriales, en las últimas décadas del siglo XIX. Para ello, se estudia el contexto de la Guerra de Castas de Yucatán, el cual puso en evidencia la presencia de otros actores: los indios mayas. Se trata en este caso de entender cómo el poder local de Honduras Británica, declarado colonia desde 1862, construyó sus propios conocimientos territoriales y los transmitió a las autoridades de Londres para explicar y argumentar sus iniciativas y propuestas políticas.

En el texto se señala cómo, a todo lo largo del siglo XIX, la gran pregunta en cuanto a la gestión y el control del territorio tuvo que ver con la indefinición de las fronteras. En particular, la cuestión de la frontera con México debió ser resuelta en el contexto de la Guerra de Castas en Yucatán y de su posible extensión a Honduras Británica.

Hoffmann explica cómo la seguridad y la defensa del territorio llevaron a los británicos a elaborar una propuesta de contención frente a este conflicto, basada en la construcción de infraestructura y la presencia de fuerzas represivas en la franja fronteriza. Además, demuestra cómo esta propuesta se hace evidente en la cartografía de la época, en donde pueden rastrearse los diversos proyectos de control de la frontera norte del territorio de Honduras Británica.

Igualmente, nos dice, los mapas de entonces sirvieron como sustento para informar a Londres sobre las relaciones establecidas entre el gobierno de Honduras Británica y los grupos indígenas de Yucatán, así como de las implicaciones políticas de estos vínculos. En este sentido, Hoffmann indica que las autoridades británicas fueron acusadas muchas veces de apoyar a los grupos rebeldes, facilitándoles armas a cambio de que no incursionaran ni expandieran el conflicto armado del lado de Honduras Británica, al tiempo que los madereros negociaban individualmente con los grupos mayas el acceso a los recursos forestales de los territorios que éstos controlaban.

Por último, la autora destaca la cuestión de la delimitación de la frontera con Guatemala, asunto también fundamental en ese momento. Señala las dificultades tanto técnicas como diplomáticas para negociar 
con las autoridades guatemaltecas y con los indígenas presentes en las montañas, sobre todo los Icaiché.

$\mathrm{Al}$ respecto, Hoffman demuestra cómo, en el discurso oficial, las poblaciones mayas estaban ausentes en las discusiones sobre la cuestión del territorio y sus fronteras. Si bien el espacio indígena parece, según los mapas, detenerse en las fronteras de la colonia, se sabe por otras fuentes que esto no era así. En su opinión, la cartografía tenía objetivos claramente estratégicos y militares, y daba cuenta de una visión anglo-centrista, según la cual los actores armados estaban siempre en el exterior, aunque muy cercanos y potencialmente peligrosos para el territorio colonial.

Odile Hoffmann concluye que, hasta el siglo XVII, el espacio que actualmente ocupa Belice aparecía en las representaciones cartográficas como una porción de continente en el nuevo mundo sin un atributo particular, que no fuera el de confines mal conocidos por los europeos. Más tarde, durante el siglo XVIII, los mapas dibujaban un área con límites inciertos, un espacio codiciado que faltaba delimitar y un objeto de negociación entre los imperios. Ya en el siglo XIX, su elaboración se insertó en las lógicas coloniales como un territorio por controlar y administrar.

Nos explica que fue entonces cuando los mapas comenzaron a multiplicarse. Éstos fueron producidos por los grupos dominantes y reflejaron sus preocupaciones e intereses, en este caso principalmente forestales, mientras que los subordinados estaban ausentes de la mayoría de estas representaciones, las cuales no proporcionaban información acerca de la población en su diversidad demográfica o étnica.

En suma, señala la autora, los mapas producidos por la administración colonial guardaron silencio sobre los actores locales. No había nada acerca de los esclavos presentes desde el inicio de la llegada de los europeos, nada acerca de los inmigrantes que arribaron durante todo el siglo XIX, nada de los garífunas que estaban ahí desde principios del siglo XIX, y nada acerca de los pueblos mayas que habitaron esas tierras desde tiempos remotos. 
Sus orígenes eran vistos como ajenos al territorio y su ausencia en los mapas corresponde a la exclusión de los no-blancos de la comunidad política que se estaba gestando en Honduras Británica. En el discurso colonial, sostiene la autora, los mayas, los esclavos y sus descendientes aparecían como extranjeros que llegaron a Honduras Británica después de la instalación europea y su exclusión puso en evidencia la división racial y étnica que determinaba las relaciones de dominación/sumisión en el territorio, todo lo cual fue reflejado en las expresiones cartográficas de la época.

Finalmente, deseo destacar que la colección de mapas presentada en este libro es por sí misma invaluable, pues pone estos documentos al alcance tanto de los estudiosos de la historia de Belice, como de los beliceńos en general, además de haber sido editados a color de manera impecable. A ello se agrega el análisis de Odile Hoffmann, que nos demuestra de manera contundente que los mapas no son instrumentos neutrales, sino que siempre llevan implícito un contenido político y responden a los intereses de los grupos que entran en disputa por el territorio.

Sin embargo, la autora abre una luz de esperanza al reconocer que una nueva revolución está teniendo lugar hoy en la cartografía, ya que las técnicas permiten su apropiación por parte de grupos sociales anteriormente excluidos. Así, en el sur de Belice, en el distrito de Toledo, habitado por grupos mayas que están luchando por el reconocimiento de sus derechos territoriales, se ha elaborado un atlas producto de una cartografía comunitaria. Este proyecto permite vislumbrar hoy la posibilidad de construir una legitimidad territorial en la que los colonizados de ayer puedan tener la palabra.

\section{Mónica Toussaint ${ }^{3}$ Instituto Mora}

\footnotetext{
${ }^{3}$ Doctora en Estudios Latinoamericanos por la UNAM. Profesora-investigadora del Instituto de Investigaciones Dr. José María Luis Mora. Temas: historia de las relaciones México-Centroamérica-Estados Unidos, historia de la frontera sur, historia de Belice, historia de la política exterior de México, historia oral de la diplomacia mexicana, problemas de la posguerra en Centroamérica. Correo electrónico: moniesca@gmail.com
} 